\title{
Roles of Alloying Elements on the Passivity of W-xCr-yNi Alloys in Aggressive Environments
}

\author{
P. L. Kharel, ${ }^{1}$ S. P. Sah ${ }^{2}$ and J. Bhattarai ${ }^{1}$ \\ ${ }^{1}$ Central Department of Chemistry, Tribhuvan University, Kathmandu \\ ${ }^{2}$ Nepal Academy of Science \& Technology (NAST), Khumaltar, Lalitpur \\ e-mail:bhattarai_05@yahoo.com
}

\begin{abstract}
The role of alloying elements on the passivity of the sputter-deposited amorphous or nanocrystalline $\mathrm{W}-\mathrm{xCr}-\mathrm{yNi}$ alloys in $12 \mathrm{M} \mathrm{HCl}, 0.5 \mathrm{M} \mathrm{NaCl}$ and $1 \mathrm{M} \mathrm{NaOH}$ solutions open to air at $30^{\circ} \mathrm{C}$ was studied by corrosion tests and electrochemical measurements. All the examined sputter-deposited W-(42-75)Cr-(4-15)Ni alloys, which are composed of either amorphous or nanocrystalline single phase solid solution, showed higher corrosion resistance than those of alloying elements (i.e. tungsten, chromium and nickel) in $12 \mathrm{M} \mathrm{HCl}, 0.5 \mathrm{M} \mathrm{NaCl}$ and $1 \mathrm{M} \mathrm{NaOH}$ solutions. All the alloys used in this study showed higher corrosion resistance than those of the alloying elements in the aggressive environments. Anodic current densities of the alloys decreased with increasing chromium contents and became lower than that of chromium. Transpassive dissolution of chromium was significantly enhanced by the simultaneous additions of tungsten, chromium and nickel in aggressive environments of $12 \mathrm{M} \mathrm{HCl}, 0.5 \mathrm{M} \mathrm{NaCl}$ and $1 \mathrm{M} \mathrm{NaOH}$. Hence the synergistic effect of chromium addition in enhancing the corrosion resistance of the $\mathrm{W}$-xCr-yNi alloys was clearly observed from the present study.
\end{abstract}

Key words: W-xCr-yNi alloys, sputter deposition, corrosion resistance, $12 \mathrm{M} \mathrm{HCl}, 0.5 \mathrm{M} \mathrm{NaCl}, 1 \mathrm{M} \mathrm{NaOH}$

\section{Introduction}

The chemically homogeneous single-phase nature of amorphous or/and nanocrystalline alloys is generally responsible for their high corrosion resistance owing to the formation of uniform protective passive films which are able to separate bulk of alloys from aggressive environments. In recent years, the use of the sputter deposition technique is becoming a quite suitable for tailoring of varieties of amorphous or/and nanocrystalline corrosion-resistant alloys, because the sputter deposits are considered to be homogeneous alloys from corrosion point of view.

Tungsten, chromium and nickel are known as effective alloying elements in enhancing the corrosion resistance properties of alloys in aggressive environments. It has been reported that the sputterdeposited amorphous or/and nanocrystalline tungsten-based W-xTi (Bhattarai 2009a, 2009b, Bhattarai et al. 1995, Sharmah et al. 2007), W-xNi (Bhattarai 2001, Sah \& Bhattarai 2008/2009), W-xNb
(Bhattarai 2011a, Bhattarai et al. 1998a, 1998b, Jha \& Bhattarai 2008), W-xCr (Bhattarai et al. 1998c, Bhattarai \& Hashimoto 1998, Basnet and Bhattarai 2010), WxTa (Bhattarai 2011b, 2012a, Bhattarai \& Baral 2013, Bhattarai et al. 1998d), W-xMo (Bhattarai 2006, 2012b, Khadka \& Bhattarai 2010), W-xZr (Bhattarai et al. 1997, Shrestha \& Bhattarai 2010), W-xZr-yCr (Aryal \& Bhattarai 2010, 2011, Bhattarai 2010a, 2011c, 2011d, Kumal \& Bhattarai 2011) and W-xCr-yNi (Bhattarai 2009c, 2010b, Bhattarai \& Kharel 2009-10, Kharel \& Bhattarai 2009) alloys were spontaneously passivated showing significantly higher corrosion resistance than those of alloy-constituting elements in aggressive solutions. The significant improvement of the corrosion resistance properties of these alloys is attributed to the formation of double oxyhydroxide passive films containing both tungsten and alloyconstituting metal cations.

On the other hand, chromium is one of the corrosionresistant elements in aggressive environments, 
although it suffers transpassive dissolution by anodic polarization in chloride containing solutions. The alloying of chromium with zirconium (Kim et al. 1993a, Li et al. 1997a), titanium (Kim et al. 1993b, Li et al. 1997b), niobium and tantalum (Kim et al. 1994), molybdenum (Park et al. 1995) and tungsten (Bhattarai et al. 1998c, Bhattarai \& Hashimoto 1998) greatly improved the corrosion resistance of the alloys in acidic solutions. In particular, it has been reported that only 10 at\% of tungsten addition was enough to cause spontaneous passivation of the nanocrystalline $\mathrm{W}$ $\mathrm{xCr}$ alloys in $12 \mathrm{M} \mathrm{HCl}$ solution and these alloys showed lower corrosion rates than those of tungsten and chromium (Bhattarai et al. 1998c). Furthermore, chromium is proved as one of the most effective alloying elements to provide a high passivating ability particularly for showing high pitting corrosion resistance of the sputter-deposited binary $\mathrm{Cr}-\mathrm{Zr}$ alloys (Kim et al. 1993a, Li et al. 1997a) and Mo-Cr alloys (Park et al. 1995) in hydrochloric acid solutions. Similarly, a series of the sputter-deposited chromiummetalloid alloys exhibited superior corrosion resistance properties compared to chromium metal in $\mathrm{HCl}$ solutions (Moffat et al. 1995).

Furthermore, it has been reported that the sputterdeposited amorphous or/and nanocrystalline W-Ni alloys were passivated spontaneously and tungsten addition greatly enhances the corrosion resistance properties of nickel in $12 \mathrm{M} \mathrm{HCl}$ (Bhattarai 2001). It is noteworthy for mentioning here that both chromium (Pourbaix 1974a) and nickel (Pourbaix 1974b) metals are very corrodible in acidic or very alkaline $(>13 \mathrm{pH})$ solutions containing oxidizing agents. However, both chromium and nickel metals do not generally corrode in alkaline solutions like $1 \mathrm{M} \mathrm{NaOH}$, mostly due to the formation of chromium hydroxide/oxides (Pourbaix 1974a) and nickel hydroxide/oxides (Pourbaix 1974b), respectively. On the other hand, tungsten metal is actively dissolved even in slightly alkaline solution as well as in solution having $\mathrm{pH}$ of 4 or high (Pourbaix 1974c). Accordingly, it might be expected that effects of tungsten, chromium and nickel additions enhance in the corrosion resistance properties of the sputterdeposited amorphous or nanocrystalline $\mathrm{W}$-xCr-(415)Ni alloys in $12 \mathrm{M} \mathrm{HCl}, 0.5 \mathrm{M} \mathrm{NaCl}$ and $1 \mathrm{M} \mathrm{NaOH}$ solutions.

In this context, the present research is aimed to clarify the roles of tungsten, zirconium and chromium additions on the passivity of the ternary $\mathrm{W}$-xCr-(415)Ni alloys in different aggressive environments, that is, in $12 \mathrm{M} \mathrm{HCl}, 0.5 \mathrm{M} \mathrm{NaCl}$ and $1 \mathrm{M} \mathrm{NaOH}$ solutions.

\section{Methodology}

The sputter-deposited ternary $\mathrm{W}-\mathrm{xCr}-\mathrm{yNi}$ alloys containing 42-75 chromium and 4-15 nickel were characterized as single-phase solid solutions of amorphous or/and nanocrystalline structures having apparent grain size ranges from 1.5 to $10.2 \mathrm{~nm}$ (Bhattarai 2009c, 2010b, Bhattarai \& Kharel 2009-10, Kharel \& Bhattarai 2009). The composition of the sputterdeposited $\mathrm{W}-\mathrm{xCr}-\mathrm{yNi}$ alloys hereafter is denoted in atomic percentage (at\%).

Prior to corrosion tests and electrochemical measurements, the surface of the sputter-deposited ternary $\mathrm{W}-\mathrm{xCr}-\mathrm{yNi}$ alloy specimens was polished mechanically with silicon carbide paper grit No. 1500 in cyclohexane, rinsed with acetone and dried in air. Corrosion rates of the $\mathrm{W}-\mathrm{xCr}-\mathrm{yNi}$ alloys including tungsten, chromium and nickel metals were estimated from the weight loss after immersion for $168 \mathrm{~h}$ in $12 \mathrm{M}$ $\mathrm{HCl}, 0.5 \mathrm{M} \mathrm{NaCl}$ and $1 \mathrm{M} \mathrm{NaOH}$ solutions open to air at $30^{\circ} \mathrm{C}$. Potentiodynamic anodic polarization curves were measured after immersion for 30 minutes in $12 \mathrm{M}$ $\mathrm{HCl}, 0.5 \mathrm{M} \mathrm{NaCl}$ and $1 \mathrm{M} \mathrm{NaOH}$ solutions at $30^{\circ} \mathrm{C}$ when the open circuit potential became almost steady. The scan rate of the polarized potential was adjusted at $1 \mathrm{mV} \cdot \mathrm{s}^{-1}$. A platinum mesh and a saturated calomel electrode (SCE) were used as counter and reference electrodes, respectively. All the potential given in this paper are relative to SCE.

\section{Results and Discussion}

Figure 1 shows corrosion rates of the sputterdeposited amorphous or nanocrystalline $\mathrm{W}-(42-75) \mathrm{Cr}$ (4-15)Ni alloys after immersion for $168 \mathrm{~h}$ in different aggressive environments at $30^{\circ} \mathrm{C}$. The corrosion rates of the sputter-deposited tungsten, chromium and nickel metals are also shown for comparison. The additions of $42-75$ at\% chromium and 4-15 at\% nickel in the $\mathrm{W}-\mathrm{xCr}-\mathrm{yNi}$ alloys significantly enhanced the corrosion resistance properties of the alloys in aggressive $12 \mathrm{M} \mathrm{HCl}, 0.5 \mathrm{M} \mathrm{NaCl}$ and $1 \mathrm{M} \mathrm{NaOH}$ solutions. As a result, the corrosion rates of the $\mathrm{W}$ $\mathrm{xCr}-\mathrm{yNi}$ alloys, which are composed of either amorphous or nanocrystalline phase, are lower than those of alloying elements in the corrosive environments. Furthermore, all the examined alloys 


\section{P. L. Kharel et al./Roles of Alloying Elements.}

showed higher corrosion rates in $12 \mathrm{M} \mathrm{HCl}$ solution than those in $0.5 \mathrm{M} \mathrm{NaCl}$ and $1 \mathrm{M} \mathrm{NaOH}$ solutions. It is meaningful for mentioning here that the corrosion rates of these ternary alloys were found to be lower than those of the sputter-deposited binary W-(42-75)Cr (Basnet and Bhattarai 2010, Bhattarai et al. 1998c) and W-(4-15)Ni (Bhattarai 2001, Sah \& Bhattarai 2008/2009) alloys in $12 \mathrm{M} \mathrm{HCl}, 0.5 \mathrm{M} \mathrm{NaCl}$ and $1 \mathrm{M} \mathrm{NaOH}$ solutions.

In particular, corrosion rates of the $\mathrm{W}-\mathrm{xCr}-(4-15) \mathrm{Ni}$ alloys containing 42-75 at\% chromium were found to be lower than that of the sputter-deposited $\mathrm{W}-15 \mathrm{Ni}$ alloys in $12 \mathrm{M} \mathrm{HCl}$ solution (Bhattarai 2009c). Consequently, a small addition of nickel was found to be detrimental for the corrosion resistance properties of the W-Cr-Ni alloys in $12 \mathrm{M} \mathrm{HCl}$ solution (Bhattarai 2009c). On the other hand, the corrosion rates of tungsten, chromium and nickel are about $2.5 \times 10^{-2}$ $\mathrm{mm} . \mathrm{y}^{-1}, 7.4 \times 10^{-3} \mathrm{~mm} . \mathrm{y}^{-1}$ and $3.0 \times 10^{-1} \mathrm{~mm} \cdot \mathrm{y}^{-1}$, respectively, in $0.5 \mathrm{M} \mathrm{NaCl}$ solution. It is noteworthy to mention here that corrosion rate of the sputterdeposited binary W-(4-15)Ni alloys was found to be in the range of $1.95 \times 10^{-2}-2.12 \times 10^{-2} \mathrm{~mm} \cdot \mathrm{y}^{-1}$ in $0.5 \mathrm{M} \mathrm{NaCl}$ solution (Sah \& Bhattarai 2008/2009). The corrosion rates of the W-Cr-(4-15)Ni alloys containing 42-75 at\% chromium were about one order of magnitude lower than those of the sputter-deposited W-(7-15)Ni alloys and tungsten, and even lower than that of the sputterdeposited chromium (Bhattarai \& Kharel 2009-10). These results clearly revealed that the addition of chromium to the $\mathrm{W}-(4-15) \mathrm{Ni}$ alloys is effective in enhancing the corrosion resistance of the sputterdeposited W-Cr-(4-15)Ni alloys in $0.5 \mathrm{M} \mathrm{NaCl}$ solution. Consequently, the addition of 42-75 at\% chromium content to the sputter-deposited binary $\mathrm{W}-(4-15) \mathrm{Ni}$ alloys is very effective in enhancing the corrosion resistance properties of the sputter-deposited W-Cr(4-15)Ni alloys in neutral $0.5 \mathrm{M} \mathrm{NaCl}$ solution.

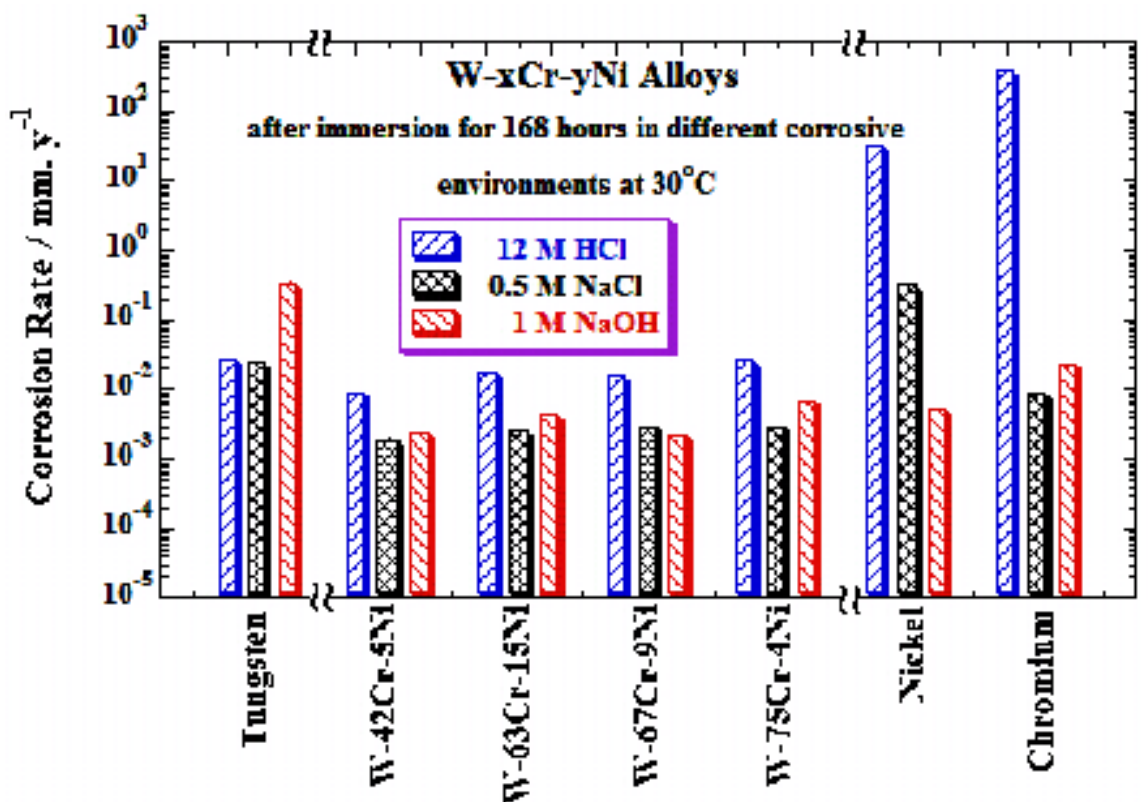

Fig. 1. Changes of corrosion rates of the sputter-deposited $\mathrm{W}-\mathrm{xCr}-\mathrm{yNi}$ alloys including tungsten, chromium and nickel in $12 \mathrm{M} \mathrm{HCl}, 0.5 \mathrm{M} \mathrm{NaCl}$ and $1 \mathrm{M} \mathrm{NaOH}$ solutions open to air at $30^{\circ} \mathrm{C}$

Similarly, the corrosion rates of the sputter-deposited binary $\mathrm{W}-(4-15) \mathrm{Ni}$ alloys were found to be in the range of about $2.1 \times 10^{-2}-3.0 \times 10^{-1} \mathrm{~mm} . \mathrm{y}^{-1}$ in $1 \mathrm{MNaOH}$ solution (Kharel \& Bhattarai 2009). However, the corrosion rates of the sputter-deposited W-Cr-(4-15)Ni alloys containing 42-75 at\% chromium are about two orders of magnitude lower than those of the sputter- deposited W-(7-9)Ni alloys and tungsten, and about one order of magnitude lower than those of sputterdeposited W-(4-15)Ni alloys as well as chromium metal in $1 \mathrm{M} \mathrm{NaOH}$ solution from the present study. Consequently, the addition of $42-75$ at $\%$ chromium to the sputter-deposited binary $\mathrm{W}-(4-15) \mathrm{Ni}$ alloys is very effective in enhancing the corrosion resistance of 
the W-Cr-(4-15)Ni alloys in $1 \mathrm{M} \mathrm{NaOH}$ solution. From above discussion, it can be concluded that the simultaneous additions of tungsten and chromium with small amounts of nickel containing 4-15 at\% enhance synergistically the corrosion resistance properties of the sputter-deposited ternary $\mathrm{W}-\mathrm{xCr}-\mathrm{yNi}$ alloys containing $42-75$ at\% chromium in aggressive $12 \mathrm{M}$ $\mathrm{HCl}, 0.5 \mathrm{M} \mathrm{NaCl}$ and $1 \mathrm{M} \mathrm{NaOH}$ solutions.

Electrochemical measurements were carried out for a better understanding of the high corrosion resistance properties of the sputter-deposited amorphous or/and nanocrystalline $\mathrm{W}-\mathrm{xCr}-\mathrm{yNi}$ alloys in $12 \mathrm{M} \mathrm{HCl}, 0.5 \mathrm{M}$ $\mathrm{NaCl}$ and $1 \mathrm{M} \mathrm{NaOH}$ solutions open to air at $30^{\circ} \mathrm{C}$. Figures 2-4 show the changes in the corrosion rates and the open circuit corrosion potentials of the alloys in $12 \mathrm{M} \mathrm{HCl}, 0.5 \mathrm{M} \mathrm{NaCl}$ and $1 \mathrm{M} \mathrm{NaOH}$ solutions in the given conditions, as a function of alloy chromium content. The open circuit corrosion potential of the alloys in $12 \mathrm{M} \mathrm{HCl}$ solution is shifted to more negative direction with increasing the chromium content in the ternary W-xCr-yNi alloys (Fig. 2), while the open circuit corrosion potential of all the examined alloys in $0.5 \mathrm{M}$ $\mathrm{NaCl}$ (Fig. 3) and $1 \mathrm{M} \mathrm{NaOH}$ (Fig. 4) solutions is shifted to more positive direction with increasing the chromium content in the alloys. In particular, the sputter-deposited W-xCr-yNi alloys containing 63-75 at\% chromium showed the most noble open circuit corrosion potential than those of $\mathrm{W}-42 \mathrm{Cr}-5 \mathrm{Ni}$ alloy, tungsten and chromium metals both in $0.5 \mathrm{M} \mathrm{NaCl}$ (Fig. 3) and in $1 \mathrm{M} \mathrm{NaOH}$ (Fig. 4) solutions. These results revealed that high corrosion resistance of the ternary $\mathrm{W}-\mathrm{xCr}-\mathrm{yNi}$ alloys is mostly due to the ennoblement of the open circuit corrosion potential of the alloys in $0.5 \mathrm{M} \mathrm{NaCl}$ and $1 \mathrm{M} \mathrm{NaOH}$ solutions at $30^{\circ} \mathrm{C}$. Consequently, the sputter-deposited $\mathrm{W}-\mathrm{xCr}-$ yNi alloys containing adequate amounts of tungsten and chromium showed the more stable passivity and showed higher corrosion resistance than those of alloy-constituting elements (i.e., tungsten, chromium and nickel) in $0.5 \mathrm{M} \mathrm{NaCl}$ and $1 \mathrm{M} \mathrm{NaOH}$ solutions.

On the other hand, the open circuit corrosion potentials of all the examined $\mathrm{W}$-xCr-yNi alloys in 12 $\mathrm{M} \mathrm{HCl}$ are located between the open circuit corrosion potentials of tungsten and chromium, but mostly very close to that of tungsten as shown in Fig. 2. It is meaningful to mention here that the open circuit corrosion potential of the $\mathrm{W}$-xCr-yNi alloys containing 42-67 at\% chromium are located very close to the passive regions of the chromium metal and active regions of nickel metal as shown in Fig. 5. Accordingly, the additions of chromium and tungsten enhance the corrosion resistance properties of the sputterdeposited ternary $\mathrm{W}-\mathrm{xCr}-\mathrm{yNi}$ alloys and such a beneficial effect of nickel metal cannot observed as shown in Fig. 1.

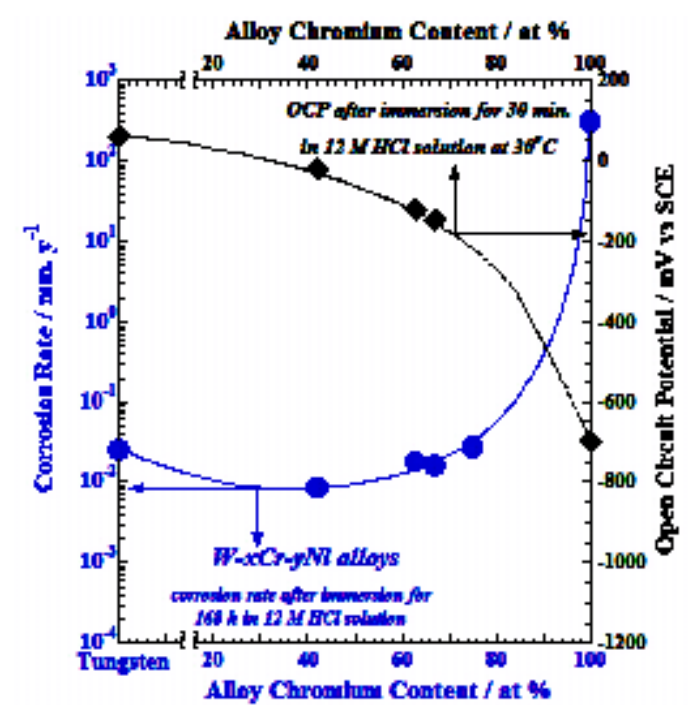

Fig. 2. Changes in corrosion rates and open circuit corrosion potentials of the sputter-deposited $\mathrm{W}-\mathrm{xCr}-\mathrm{yNi}$ alloys including tungsten and chromium in $12 \mathrm{M}$ $\mathrm{HCl}$ solution open to air at $30^{\circ} \mathrm{C}$

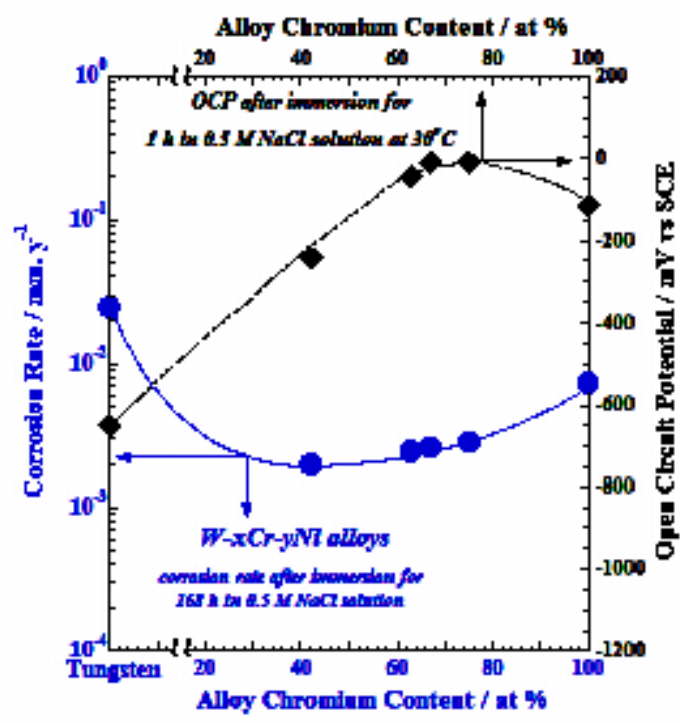

Fig. 3. Changes in corrosion rates and open circuit corrosion potentials of the sputter-deposited $\mathrm{W}-\mathrm{xCr}-\mathrm{yNi}$ alloys including tungsten and chromium in $0.5 \mathrm{M}$ $\mathrm{NaCl}$ solution open to air at $30^{\circ} \mathrm{C}$ 
Figures 5, 6 and 7 show the potentiodynamic anodic polarization curves for the ternary $\mathrm{W}-\mathrm{xCr}-\mathrm{yNi}$ alloys after immersion for 30 minutes in $12 \mathrm{M} \mathrm{HCl}, 0.5 \mathrm{M} \mathrm{NaCl}$ and $1 \mathrm{M} \mathrm{NaOH}$ solutions, respectively, at $30^{\circ} \mathrm{C}$ to determine the roles of tungsten, chromium and nickel additions on the anodic passivity of the alloys in the aggressive environments. The anodic polarization curves for the sputter-deposited tungsten, chromium and nickel metals are also shown for comparison.

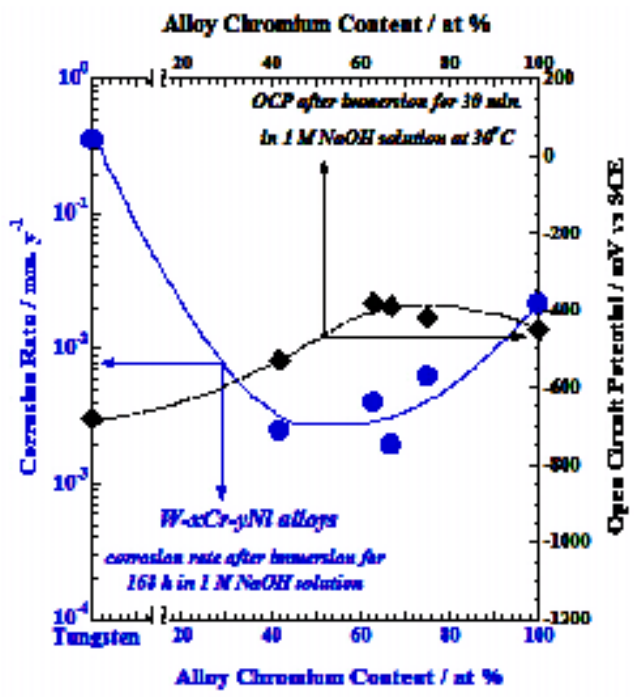

Fig. 4. Changes in corrosion rates and open circuit corrosion potentials of the sputter-deposited $\mathrm{W}-\mathrm{xCr}-\mathrm{yNi}$ alloys including tungsten and chromium in $1 \mathrm{M}$ $\mathrm{NaOH}$ solution open to air at $30^{\circ} \mathrm{C}$

All the examined $\mathrm{W}$-xCr-yNi alloys as well as tungsten metal are spontaneously passivated in $12 \mathrm{M}$ $\mathrm{HCl}$ in contrast to chromium and nickel metals those show the active-passive transitions as shown in Fig. 5. Chromium metal shows the transpassive dissolution at about $0.80 \mathrm{~V}$ vs SCE mostly due to the formation of hexavalent chromium ion in $12 \mathrm{M} \mathrm{HCl}$ solution. The anodic current densities of the sputter-deposited W$\mathrm{xCr}-\mathrm{yNi}$ alloys decrease with increasing the chromium content in the alloys. The $\mathrm{W}-75 \mathrm{Cr}-4 \mathrm{Ni}$ alloy shows the lowest anodic current density among the examined alloys in this study. It is noteworthy to mention that the anodic current densities of the alloys are significantly lower than those of the alloying elements (i.e., tungsten, chromium and nickel). Accordingly, the protective quality of the anodic passive films formed on the sputter-deposited $\mathrm{W}-\mathrm{xCr}-\mathrm{yNi}$ alloys is better than those of allying elements even in very aggressive environment of $12 \mathrm{M} \mathrm{HCl}$ solution at $30^{\circ} \mathrm{C}$.
Similarly, all the examined $\mathrm{W}$-xCr-yNi alloys as well as tungsten, chromium and nickel metals are spontaneously passivated in both $0.5 \mathrm{M} \mathrm{M} \mathrm{NaCl}$ and $1 \mathrm{M} \mathrm{NaOH}$ solutions open to air at $30^{\circ} \mathrm{C}$ as shown in Figs 6 and 7. However, all the alloys including nickel and chromium metals showed the transpassive dissolution at higher anodic potential regions. In general, the transpassive dissolution potential of all the examined alloys in $0.5 \mathrm{M} \mathrm{NaCl}$ solution was found to be shifted to more positive or noble direction than in $1 \mathrm{M} \mathrm{NaOH}$ solution. The anodic current density of the alloys is decreased with increasing the chromium content in the alloys in both $0.5 \mathrm{M} \mathrm{NaCl}$ and $1 \mathrm{M}$ $\mathrm{NaOH}$ solutions.

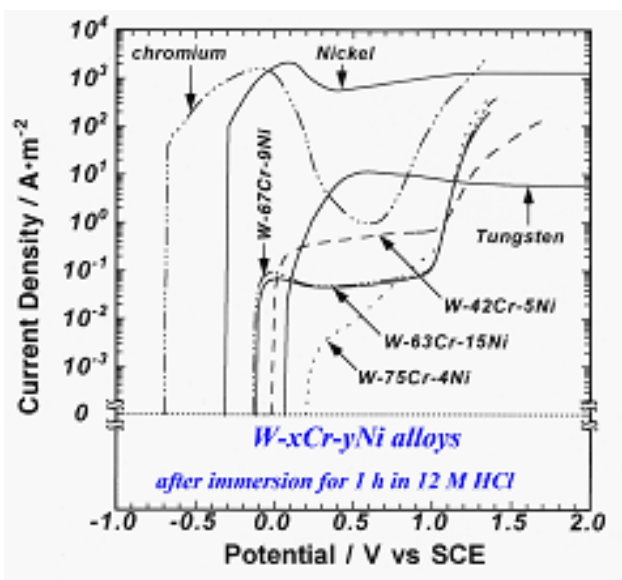

Fig. 5. Potentiodynamic polarization curves for the sputterdeposited ternary $\mathrm{W}-\mathrm{xCr}-\mathrm{yNi}$ alloys including sputter-deposited tungsten, chromium and nickel metals in $12 \mathrm{M} \mathrm{HCl}$ solution open to air at $30^{\circ} \mathrm{C}$

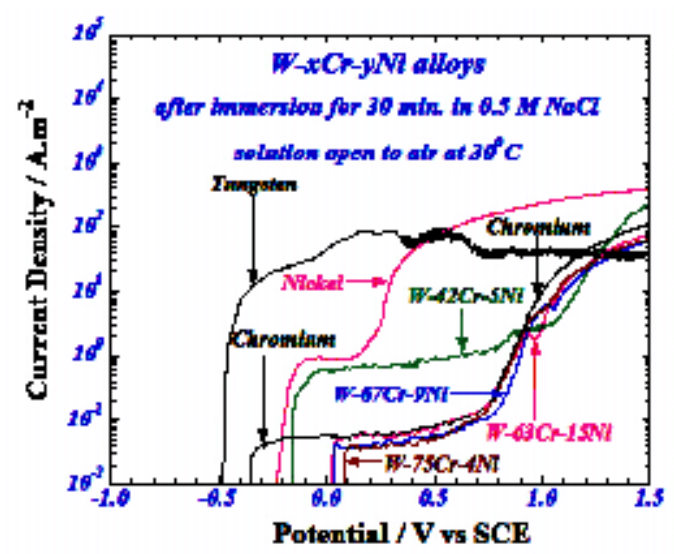

Fig. 6. Potentiodynamic polarization curves for the sputterdeposited ternary $\mathrm{W}-\mathrm{xCr}-\mathrm{yNi}$ alloys including sputter- deposited tungsten, chromium and nickel metals in $0.5 \mathrm{M} \mathrm{NaCl}$ solution open to air at $30^{\circ} \mathrm{C}$ 


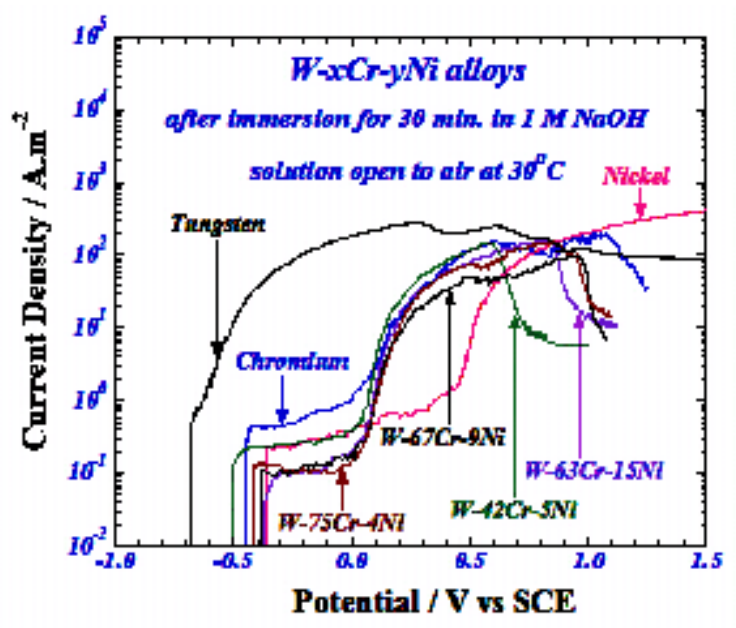

Fig. 7. Potentiodynamic polarization curves for the sputterdeposited ternary $\mathrm{W}-\mathrm{xCr}-\mathrm{yNi}$ alloys including sputter-deposited tungsten, chromium and nickel metals in $1 \mathrm{M} \mathrm{NaOH}$ solution open to air at $30^{\circ} \mathrm{C}$

In particular, the current density of the $\mathrm{W}-42 \mathrm{Cr}-5 \mathrm{Ni}$ alloy is slightly higher than those of other $\mathrm{W}-\mathrm{xCr}-\mathrm{yNi}$ alloys in both $0.5 \mathrm{M} \mathrm{NaCl}$ and $1 \mathrm{M} \mathrm{NaOH}$ solutions. These results revealed that the protective quality of the anodic passive films formed on the sputterdeposited $\mathrm{W}-\mathrm{xCr}-\mathrm{yNi}$ alloys is better than those films formed on the allying elements in both $0.5 \mathrm{M} \mathrm{NaCl}$ and $1 \mathrm{M} \mathrm{NaOH}$ solutions. The open circuit corrosion potential of all the examined ternary $\mathrm{W}-\mathrm{xCr}-\mathrm{yNi}$ alloys in both $0.5 \mathrm{M} \mathrm{NaCl}$ and $1 \mathrm{M} \mathrm{NaOH}$ solutions is shifted to more positive or noble direction than those of the sputter-deposited tungsten and chromium. These results are in support of the results of corrosion studies as shown in Fig. 1.

In summary, the synergistic effects of the simultaneous additions of tungsten, chromium and nickel in enhancing the corrosion resistance of the amorphous or/and nanocrystalline $\mathrm{W}-\mathrm{xCr}-\mathrm{yNi}$ alloys containing 42-75 at\% chromium and 4-15 at\% nickel is clearly observed in $12 \mathrm{M} \mathrm{HCl}, 0.5 \mathrm{M} \mathrm{NaCl}$ and $1 \mathrm{M} \mathrm{NaOH}$ solutions open to air at $30^{\circ} \mathrm{C}$ and hence all the examined sputter-deposited ternary W-xCr-yNi alloys showed higher corrosion resistance than those of alloyconstituting elements (i.e., tungsten, chromium and nickel). The simultaneous additions of chromium and nickel to tungsten metal provided outstanding improvement in the protective quality of the anodic passive film in comparison with the single addition of tungsten or chromium on zirconium and hence both tungsten and chromium act synergistically in enhancing the transpassive dissolution of chromium metal in aggressive environments. The open circuit corrosion potentials of the $\mathrm{W}-63 \mathrm{Cr}-15 \mathrm{Ni}, \mathrm{W}-67 \mathrm{Cr}-$ $9 \mathrm{Ni}$ and $\mathrm{W}-75 \mathrm{Cr}-4 \mathrm{Ni}$ alloys are shifted to more noble (or positive) direction than those of all alloyconstituting elements after immersion for 30 minutes in all corrosive environments used in the present study.

\section{Acknowledgments}

The authors would like to express their special gratitude to Professor Emeritus K. Hashimoto and K. Asami of Tohoku University and Professor H. Habazaki of Hokkaido University, Japan for their kind permission to use the $\mathrm{XRD}$, electron probe microanalysis, sputtering machine and fruitful discussions.

\section{References}

Aryal, B. R. and J. Bhattarai. 2010. Effects of alloying elements on the corrosion behavior of sputter-deposited Zr-(12-21)Cr-W alloys in $0.5 \mathrm{M} \mathrm{NaCl}$ solution. Journal of Nepal Chemical Society 25:75-82.

Aryal, B. R. and J. Bhattarai. 2011. Effects of tungsten, chromium and zirconium on the corrosion behavior of ternary amorphous $\mathrm{W}-\mathrm{Cr}-\mathrm{Zr}$ alloys in $1 \mathrm{M} \mathrm{NaOH}$ solution. Scientific World 9:39-43.

Basnet, M. and J. Bhattarai. 2010. The corrosion behavior of sputter-deposited nanocrystalline $\mathrm{W}$-Cr alloys in $\mathrm{NaCl}$ and $\mathrm{NaOH}$ solutions. Journal of Nepal Chemical Society 25:53-61.

Bhattarai, J. 2001. Electrochemical and XPS studies on the corrosion behavior of sputter-deposited amorphous W-Ni alloys in $12 \mathrm{M} \mathrm{HCl}$. Journal of Nepal Chemical Society 20: 24-40.

Bhattarai, J. 2006. Structure and corrosion behavior of sputter"deposited W"Mo alloys. Journal of Nepal Chemical Society 21:19-25.

Bhattarai, J. 2009 a. The confocal scanning laser microscopic study of the pitting corrosion on sputter"deposited W"Ti alloys in $1 \mathrm{M} \mathrm{NaOH}$ solution.Tribhuvan University Journal 26 (1):17-26.

Bhattarai, J. 2009 b. The corrosion behavior of sputter"deposited W'Ti alloys in $0.5 \mathrm{M} \mathrm{NaCl}$ solution. Nepal Journal of Science and Technology 10:109-114.

Bhattarai, J. 2009 c. The effects of chromium and nickel on the passivation behavior of sputter-deposited W-Cr$\mathrm{Ni}$ alloys in $12 \mathrm{M} \mathrm{HCl}$ solution. Scientific World 7:24-28.

Bhattarai, J. 2010 a. The corrosion behavior of sputterdeposited $\mathrm{Zr}-(12-18) \mathrm{Cr}-\mathrm{W}$ alloys in $12 \mathrm{M} \mathrm{HCl}$ solution. Journal of Nepal Chemical Society 26:13-21. 
Bhattarai, J. 2010 b. X-ray photoelectron spectroscopic analyses on the corrosion-resistant $\mathrm{W}-\mathrm{Cr}-\mathrm{Ni}$ alloys in $12 \mathrm{M} \mathrm{HCl}$. Transactions of the Materials Research Society of Japan 35(1):1-6.

Bhattarai, J. 2011 a. X-ray photoelectron spectroscopic study on the anodic passivity of sputter-deposited $\mathrm{W}-\mathrm{Nb}$ alloys $12 \mathrm{M} \mathrm{HCl}$ solution. Journal of Scientific Research 3(3):457-470.

Bhattarai, J. 2011 b. X'ray photoelectron spectroscopic study on the anodic passivity of sputter"deposited W'Ta alloys in $12 \mathrm{M} \mathrm{HCl}$. Nepal Journal of Science and Technology 12:139-148.

Bhattarai, J. 2011 c. The corrosion behavior of sputterdeposited ternary $\mathrm{W}-\mathrm{Zr}-(15-18) \mathrm{Cr}$ alloys in $12 \mathrm{M}$ HCl. African Journal of Pure and Applied Chemistry 5(8):212-218.

Bhattarai, J. 2011 d. Roles of alloying elements on the corrosion behavior of sputter-deposited amorphous $\mathrm{W}-\mathrm{Cr}-\mathrm{Zr}$ alloys in $0.5 \mathrm{M} \mathrm{NaCl}$ solution. Scientific World 9:34-38.

Bhattarai, J. 2012 a. A non”destructive compositional analysis of thin surface films formed on W"xTa alloys by angle resolved X"ray photoelectron spectroscopy. Bibechana 8:8-16.

Bhattarai, J. 2012 b. The passivation behavior of sputter"deposited W"xMo alloys in $0.5 \mathrm{M} \mathrm{NaCl}$ solution. Scientific World 10:29-32.

Bhattarai, J., E. Akiyama, A. Kawashima, K. Asami and K. Hashimoto. 1995. The corrosion behavior of sputterdeposited amorphous W-Ti alloys in $6 \mathrm{M} \mathrm{HCl}$ solution. Corrosion Science 37:2071-2086.

Bhattarai, J., E. Akiyama, H. Habazaki, A. Kawashima, K. Asami and K. Hashimoto. 1997. Electrochemical and XPS studies of the corrosion behavior of sputterdeposited amorphous $\mathrm{W}-\mathrm{Zr}$ alloys in 6 and $12 \mathrm{M} \mathrm{HCl}$ solutions. Corrosion Science 39:355-375.

Bhattarai, J., E. Akiyama, H. Habazaki, A. Kawashima, K. Asami and K. Hashimoto. 1998 a. Electrochemical and XPS studies of the corrosion behavior of sputterdeposited amorphous $\mathrm{W}-\mathrm{Nb}$ alloys in concentrated hydrochloric acid solutions. Corrosion Science 40: 19-42.

Bhattarai, J., E. Akiyama, H. Habazaki, A. Kawashima, K. Asami and K. Hashimoto. 1998 b. The influence of concentration of hydrochloric acid solutions on the passivation behavior of sputter-deposited tungstenrich W-Nb alloys. Corrosion Science 40:1897-1914.

Bhattarai, J., E. Akiyama, H. Habazaki, A. Kawashima, K. Asami and K. Hashimoto. 1998 c. Electrochemical and XPS studies of the passivation behavior of sputter" deposited $\mathrm{W}-\mathrm{Cr}$ alloys in $12 \mathrm{M} \mathrm{HCl}$ solution. Corrosion Science 40:155-175.

Bhattarai, J., E. Akiyama, H. Habazaki, A. Kawashima, K. Asami and K. Hashimoto. 1998 d. The passivation behavior of sputter-deposited amorphous W-Ta alloys in $12 \mathrm{M} \mathrm{HCl}$ solution. Corrosion Science 40:757-779.

Bhattarai, J. and K. Hashimoto. 1998. X-ray photoelectron spectroscopy study in the anodic passivity of sputterdeposited nanocrystalline W-Cr alloys in $12 \mathrm{M} \mathrm{HCl}$. Tribhuvan University Journal 21(2):1-16.

Bhattarai, J. and P. L. Kharel. 2009-10. Effects of chromium and tungsten on the corrosion behavior of sputterdeposited W-Cr-Ni alloys in $0.5 \mathrm{M} \mathrm{NaCl}$ solution. Journal of Institute of Science and Technology 16: 141151.

Bhattarai, J. and S. Baral. 2013. The corrosion behavior of sputter-deposited W-xTa alloys in $0.5 \mathrm{M} \mathrm{NaCl}$ solution. Nepal Journal of Science and Technology 14: 103-108.

Jha, H. and J. Bhattarai. 2008. Corrosion behavior of sputter-deposited $\mathrm{W}-\mathrm{Nb}$ alloys in $\mathrm{NaCl}$ and $\mathrm{NaOH}$ solutions. Journal of Alloys and Compounds 456:474478.

Khadka, A. and J. Bhattarai. 2010. Corrosion and electrochemical properties of nanocrystalline W-Mo alloys in $\mathrm{NaOH}$ solution. Nepal Journal of Science and Technology 11:147-151.

Kharel, P. L. and J. Bhattarai. 2009. The corrosion behavior of sputter-deposited W-Cr-(4-15)Ni alloys in $\mathrm{NaOH}$ solution. Journal of Nepal Chemical Society 24:3-11.

Kim, J. H., E. Akiyama, H. Habazaki, A. Kawashima, K. Asami and K. Hashimoto. 1993 a. The corrosion behavior of sputter-deposited amorphous chromiumzirconium alloys in $6 \mathrm{M} \mathrm{HCl}$ solution. Corrosion Science 34:1817-1827.

Kim, J. H., E. Akiyama, H. Yoshioka, H. Habazaki, A. Kawashima, K. Asami and K. Hashimoto. 1993 b. The corrosion behavior of sputter-deposited amorphous titanium-chromium alloys in 1 and $6 \mathrm{M} \mathrm{HCl}$ solutions. Corrosion Science 34:975-987.

Kim, J. H., E. Akiyama, H. Habazaki, A. Kawashima, K. Asami and K. Hashimoto. 1994. An XPS study of the corrosion behavior of sputter-deposited amorphous $\mathrm{Cr}-\mathrm{Nb}$ and $\mathrm{Cr}-\mathrm{Ta}$ alloys in $12 \mathrm{M} \mathrm{HCl}$ solution. Corrosion Science 36:511-523.

Kumal, R. R. and J. Bhattarai. 2010. Roles of alloying elements on the corrosion behavior of amorphous W$\mathrm{Zr}-(15-33) \mathrm{Cr}$ alloys in $1 \mathrm{M} \mathrm{NaOH}$ solution. Journal of Nepal Chemical Society 25:93-100.

Li, X.-Y., E. Akiyama, H. Habazaki, A. Kawashima, K. Asami and K. Hashimoto. 1997 a. An XPS study of passive films on corrosion resistant Cr-Zr alloys prepared by sputter deposition. Corrosion Science 39:1365-1380.

Li, X.-Y., E. Akiyama, H. Habazaki, A. Kawashima, K. Asami and K. Hashimoto. 1997 b. Spontaneously passivated films on sputter-deposited $\mathrm{Cr}$-Ti alloys in $6 \mathrm{M} \mathrm{HCl}$ solution. Corrosion Science 39:935-948.

Moffat, T. P., R. M. Latanision and R. R. Ruf. 1995. An Xray photoelectron spectroscopy study of chromiummetalloid alloys. Electrochimica Acta 40:1723-1734. 
Nepal Journal of Science and Technology Vol. 14, No. 2 (2013) 73-80

Park, P.Y., E. Akiyama, A. Kawashima, K. Asami and K. Hashimoto 1995. The corrosion behavior of sputterdeposited $\mathrm{Cr}-\mathrm{Mo}$ alloys in $12 \mathrm{M} \mathrm{HCl}$ solution. Corrosion Science 37:1843-1860.

Pourbaix, M. 1974 a. Chromium. in Atlas of Electrochemical Equilibrium in Aqueous Solution. National Association of Corrosion Engineers, Huston, TX, 256pp.

Pourbaix, M. 1974 b. Nickel. in Atlas of Electrochemical Equilibrium in Aqueous Solution. National Association of Corrosion Engineers, Huston, TX, 334pp.
Pourbaix, M. 1974 c. Tungsten. in Atlas of Electrochemical Equilibrium in Aqueous Solution. National Association of Corrosion Engineers, Huston, TX, 280pp.

Sharmah, A., H. Jha and J. Bhattarai. 2007. The passivation behavior of sputter-deposited W-Ti alloys in $1 \mathrm{M}$ $\mathrm{NaOH}$ solution. Journal of Nepal Chemical Society 22:17-25.

Shrestha, P. and J. Bhattarai. 2010. The passivation behavior of sputter-deposited $\mathrm{W}-\mathrm{Zr}$ alloys in $\mathrm{NaCl}$ and $\mathrm{NaOH}$ solutions. Journal of Nepal Chemical Society 25:37-45. 